\title{
EDUCATION: ANCIENT AND MODERN
}

by

Kyle Edward Eidson

\author{
A thesis \\ submitted in partial fulfillment \\ of the requirements for the degree of \\ Master of Arts in Political Science \\ Boise State University
}

August 2017 
(C) 2017

Kyle Edward Eidson

ALL RIGHTS RESERVED 


\title{
BOISE STATE UNIVERSITY GRADUATE COLLEGE
}

\section{DEFENSE COMMITTEE AND FINAL READING APPROVALS}

\author{
of the thesis submitted by
}

Kyle Edward Eidson

Thesis Title: Education: Ancient and Modern

Date of Final Oral Examination: 10 March 2017

The following individuals read and discussed the thesis submitted by student Kyle Edward Eidson, and they evaluated his presentation and response to questions during the final oral examination. They found that the student passed the final oral examination.

Scott Yenor, Ph.D.

Chair, Supervisory Committee

Shelton Woods, Ph.D.

Member, Supervisory Committee

Stewart Gardner, Ph.D.

Member, Supervisory Committee

The final reading approval of the thesis was granted by Scott Yenor, Ph.D., Chair of the Supervisory Committee. The thesis was approved by the Graduate College. 


\section{DEDICATION}

To Deborah, Madeline, Mom, and Lance 


\section{ACKNOWLEDGEMENTS}

Not all educators are created equal. Thank you Drs. Scott Yenor and Stewart

Gardner. Your insights into the classics and had a profound impact on me. Thank you for teaching that their enduring ideas still matter. 


\begin{abstract}
John Dewey's progressive education differed from the classical model. The entrenchment of Dewey's progressive education at all levels of education has led to a decline in academic performance. The modern ideas of American education hardly resemble the ones it was founded on. This paper looks at a model of classical education adopted by the American founders — as well as classical education itself — and to Dewey, the preeminent scholar and philosopher of American, progressive education, whose aim was to develop an egalitarian society trained in non-traditional academics. The paper also looks at Dewey's child-centered model that contributes to sinking academic performance, and to the classical model that educated the West's greatest statesman and thinkers. The West needs a revival of the latter and a paring back of the former.
\end{abstract}




\section{TABLE OF CONTENTS}

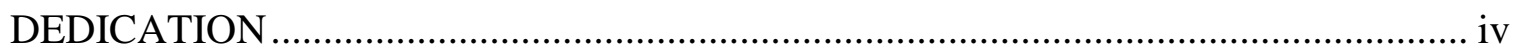

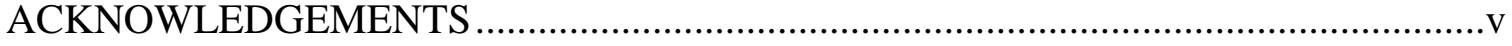

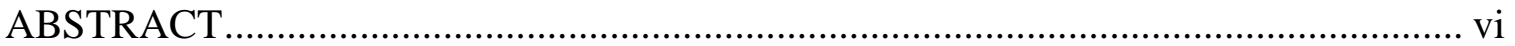

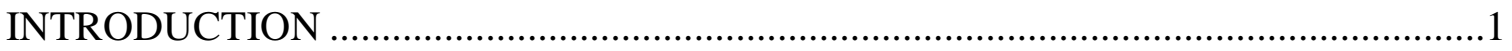

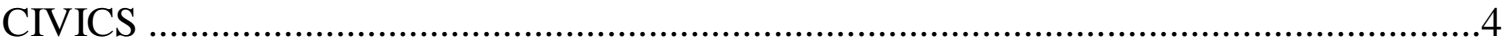

DECLINE IN GRADUATION REQUIREMENTS ..................................................

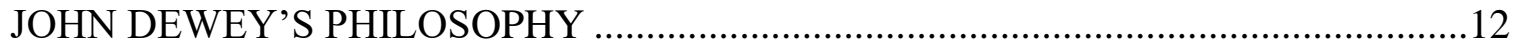

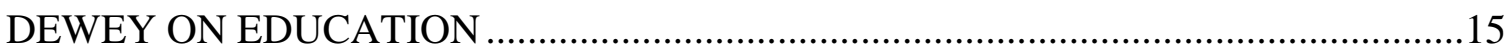

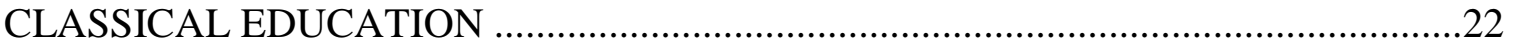

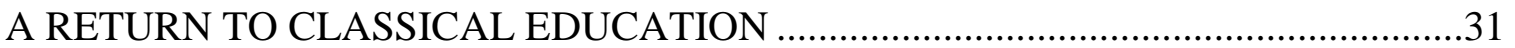

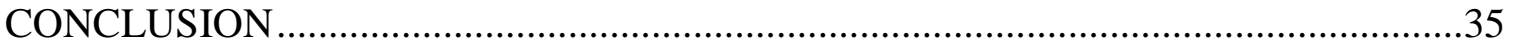

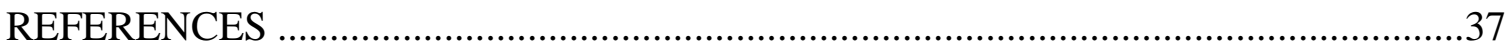




\section{INTRODUCTION}

Progressive education taught students practical things that included future work skills_-sewing, gardening, woodworking, constructing, cooking. Employment for progressive educators was critical for both the sake of democracy and economic stability. Progressives also focused on shaping social outcomes where equality among the people was achieved within diverse societies.

Conversely, classical education taught ethics, philosophy, religion, civics, science, art, exercise, the humanities, mathematics, and reading, writing and language skills. Classical subject matter relied not only on the subject matter studied, but focused on why the subject matter was important in making people with well-ordered souls. For the traditionalists, classical education was not designed for preparing future workers or contributing to some social ends. Students learned the inevitable tradeoffs that a selfgoverning people must confront and how to reduce their expectations from politics. They would learn, in other words, how to be at peace and leisure in a rather rough and tumble world.

John Dewey, the father of modern progressive education, explicitly rejected the old approach to education in his classic Democracy and Education. "We must get away from the unduly scholastic and formal notion of education," he wrote. The old model got in the way of Dewey's ideas. Classical ideas of education were obsolete, for Dewey, based, as they were, on exposing students to what the tradition had thought of as the great ideas of the great authors and great books. Instead of reading texts written in dead 
languages, as Dewey dismissively characterized the old way, schools would become places where children discovered through experience in self-directed action. Students would be immersed in the present, because, apparently, the present contained new challenges and new solutions. Acculturating students to the great challenges of the past would not be pragmatic or useful for the wholly new world of the future, the new democratic future. Education that encouraged children to use such directed freedom to discover promoted democracy, he thought (Dewey 1944, 4).

As America has moved increasingly away from the classical model, the academic performance in American schools has correspondingly declined. Knowledge of civics, reading and language skills, science, and mathematics has sunk to below average levels when compared to the rest of the world. That more tax money is spent on educationtotal taxpayer money is estimated at more than a trillion dollars in fiscal year 2017 (which is more than projected on defense spending) has done little to improve performance; academic performance has tracked the decline of academic standards (U.S. Department of Education Budget Service 2005 and National Center for Education Statistics 2016).

This decline is observable in several areas of academic importance. Civics, for instance, teaches the importance of responsible citizenship. The ancient Greeks taught that living with one another was a demanding responsibility if the citizenry was going to live harmoniously. Harmony brought citizens limited rights. However, in order to understand this give-and-take system of limited rights, citizens had to understand why laws, government institutions and their operations were critical for a peaceful political community. Early education taught that reading, thinking, writing, and speaking clearly 
and carefully were important. An inability to do these things effectively made for an ignorant political community. An ignorant citizenry made making informed political or social decisions much more difficult.

The pursuit of scientific knowledge, according to the classical model of education, was important for the maintenance of the citizen. Studying medicine and agriculture and learning the technology that makes better medicine and healthier foods benefits citizens. Science is also important so that citizens might understand the natural world. However, without the ability to think and reason effectively—skills learned through mastering grammar, logic, and rhetoric — it is much more difficult to understand and take advantage of the natural sciences (Hanson and Heath 1998).

Math is a third venue for educational excellence. For the ancients and their model of education, mathematics gave people insight into how the world is constructed. Similar to today's learners mastering a foreign language, mathematics developed logical and rational thinking within the student. Math was also important for instilling discipline and revealed problem solving skills that are embedded in the marriage of logic and data (Hanson and Heath 1998). Yet today math is linked with achieving technological advancement more than anything, leading strangely to its elevation as an important means to an even higher end. 


\section{CIVICS}

America's Founders stressed the importance of civics. The curriculum that educated the founding generation aimed at preparing future citizens for a life of responsible freedom through virtuous character. Thomas Jefferson's planned program of study for the University of Virginia, for example, included taking an ancient and modern language, a mathematics course, an applied mathematics course such as astronomy or geography, government, history, a law class, grammar, ethics, and a fine arts course. Moreover, students were trained in basic government operations. They were taught the values of republicanism, federalism, and the rule of law. In other words, early American civic education was designed to both teach students how to be excellent citizens and educate them on how the country was designed to operate to their benefit.

Classical education broadly considered has always considered ideas of political order. Aristotle defined man as "by nature an animal intended to live in a polis." He also wrote that "the good citizen is one who does good service to his state. Good citizens know both how to rule and how to obey." These ideas permeated the education of the early Greeks and later America’s founding generation (Adler 1952, 446, 473).

Education for the Greeks, for instance, dealt mainly with the political. Free citizens appreciated the duty and honor of voting in the assembly and contributed to the defense of the polis. America's founders, too, hoped that schools would teach young people how to preserve the constitutional republic they would eventually live in and rule. The founders knew that free government depended not on the decision of a few 
politicians but on the wisdom and virtue of the citizenry more than any other form of government.

Political wisdom and virtue are not easily won. More than two hundred years of American history has established that the nation can last best if we have citizens who recognize, work for, and defend America's founding principles. As much as they embraced free, constitutional government, the founders, like the ancients, feared the unbridled passions of an uneducated society, and promoted a citizenry that both understood the necessity of government and the importance of acknowledging both why they have their power as well as its source, and ultimately having a desire to participate in the civic process.

John Dewey's idea of civic education differed from the Founders. Dewey's civics focused on societal diversity and social awareness. Citizens, according to Dewey, should be recognized for their individual abilities, interests, ideas, needs, and cultural identity; they should also have developed critical, socially engaged awareness, which enabled citizens to understand and participate successfully in the concerns of their community in a cooperative effort to achieve some common good. The political needs of the country were, as Dewey saw it, always changing so that the object of civics education was the promotion of a flexible citizenship. Citizenship was different than stressing human excellence and learning about governmental operations and political institutions (University of Vermont 2017).

Evidence suggests that Dewey's model is ascendant and has had a debilitating effect on civic understanding and even on civic participation. An Academic Council of Trustees and Alumni (ACTA) (2016) study noted that a majority of American students do 
not understand traditional civic engagement as it concerns the political order; they do not know or care about their nation's system or functions of government. High school and college graduates alike performed poorly when answering basic questions regarding American democratic principles, ideas of federalism, duties of citizenship, republicanism, political processes, and the power and functions of government institutions. Furthermore, many recent surveys showed that recent college graduates are ignorant of America's history and heritage; they cannot identify the term lengths of members of Congress, do not have a basic understanding of the First Amendment, or of the origin or meaning of the separation of powers. They did not know who wrote the Constitution, or when Madison and the other founders wrote it. The lack of civic participation and civic ignorance in the modern polis is reflected in America's lack of civic knowledge and interest. (Center for Survey Research and Analysis 2000, Annenberg Public Policy Center 2014, ACTA 2016, Damon 2011).

With the notable exception of a small number of civic-minded volunteers, every kind of civic participation among young adults has declined. Consider that half of those aged 18 to 29 voted in the 1972 presidential election. However, by the late 90 s that group's voter participation dropped to about one-third. Moreover, 58 percent of college freshmen polled by UCLA in 1966 considered it important to keep up with politics; by the end of the 90s, just one quarter thought so. It is true that young Americans have more schooling than ever before. Still, they pay far less attention than previous generations did to traditional news sources and civic-minded current events (Macedo, 2004).

Studies also revealed that our colleges and universities have not addressed this lack of civic knowledge. ACTA (2016) surveyed over 1,100 liberal arts colleges and 
universities and found that just 18 percent required students to take even one survey course in American history or government before they graduated. Since 2000, institutions like the Carnegie Corporation and the American Academy of Arts and Sciences have pressed colleges and universities to take a much more active role in educating students for informed citizenship.

Progressive American institutions have exchanged the intense study of history and government — the building blocks of traditional civic engagement — with vocational-based electives and other non-academic options. Required extracurricular activities, community service and social justice programs, for instance, give students ideas about important social ideas, but no insight into how our system of government works and what roles they should fill as citizens of a constitutional republic (ACTA 2016). This may foster unreasonable hopes from political reform and contribute to disillusionment among the young.

In a country that depends on an educated populace, according to the founders, and in order to maintain a basic understanding of the country's first principles, prolonged ignorance of our history and founding documents will be devastating. An annual survey by the Newseum Institute pointed out that when asked to identify the rights guaranteed by the First Amendment, one-third of Americans could not name a single right; 43 percent were unable to even name freedom of speech as one of them (Newseum Institute 2015). 


\section{DECLINE IN GRADUATION REQUIREMENTS}

In 1996 the National Association of Scholars (NAS) published a study that examined the requirements for graduation at the top fifty US colleges. The colleges were ranked by the popular U.S. News and World Report's “Americas Best Colleges," and looked at the requirements from 1914-1993. NAS researchers discovered that while general requirements for graduation had relaxed somewhat over the course of the century, they had, to a very large extent, disappeared completely by the 1960s. The study used the official course catalogs from each institution and compared data from a four year block, three years of which were highlighted by an event that severely impacted the country's socio-economic norms during the century. 1914 marked the start of World War I and the cultural end of the nineteenth century; 1939 marked the beginning of World War II and the end of American isolationism; 1964 stood at the beginning of the massive cultural upheaval associated with the civil-rights movement and the beginning of the flood of campus protests that, with the addition of a glut of progressive influence on church, state, and parental influence, questioned and transformed the character of American academic life. The fourth year, 1993, was the last year for examining the data. By the strongest definition, an institution defines its educational priorities through the way a schedule of courses is structured; it also answers the question, "What do we want our students and future citizens to know?” (NAS 1996).

The NAS study revealed smaller numbers of required courses over time. The average number of mandatory courses dropped from 9.9 in 1914 , to 6.9 in 1964, to 2.5 in 
1993. Moreover, even without requiring a particular course in a given subject area, institutions could still limit choices by requiring students to choose at least one basic survey course from a small cluster of related courses. Even when priorities were set it was still important to know their specific content in order to assess the quality of the education being administered. Ideally, the material of a general education curriculum should certify that students would acquire the body of knowledge and the intellectual abilities necessary for personal cultivation and exhibit the satisfactory character of their obligations of citizenship (NAS 1996).

To accomplish the goals of creating good citizens with sharp minds, the NAS reasoned, students should master the essentials of the history of their people, command the basic principles and methods of the natural sciences and mathematics, and be knowledgeable with at least one foreign language; students should acquire a firm understanding of the cultural roots and heritage of their civilization through a broad exposure to its literature, philosophies, and artistic traditions, and be able to read and write the English language as the standard of personal communication (NAS 1996).

The percentage of schools that required English Composition courses for graduation declined from 98 percent in 1914, to 86 percent in 1964, and to 36 percent in 1993. Moreover, the modern English department became less important over time. The great works from the Western literature gave way to topics that focused on entertainment and leisure. Traditional areas of study have also integrated heavy levels of postmodern analyses, where great literature is seen as a basis of tolerance and social engineering instead of promoting truth and exploring universal ideals (Schalin 2015). 
Rhetoric, as a specific general education requirement, was found in one-third of all university requirements in 1914. By 1993 these requirements had disappeared. It is noteworthy, though, that rhetoric was a component of more than two-thirds of the mandatory English composition courses in 1914. In 1993 a rhetoric component existed within a regular English composition course at only two of the institutions in the study (NAS 1996).

In addition to the ability to read and write English, at least some small measure of ability in one foreign language had been a shared goal of liberal arts programs. However, the amount of agreement regarding the need of a foreign language requirement has dropped significantly among the elite schools of the NAS study. Furthermore, there are now more foreign language options available at the colleges and universities in the study that can fulfill the general education requirements. In 1914 there were on average just four foreign languages offered. On the other hand, there were on average more than thirteen foreign language choices in 1993 (NAS 1996).

Despite the broader range of foreign languages that are available in modern schools, there is a notable difference between the progressive's emphasis on "multiculturalizing" the various programs of study, and what the emphasis was on in traditional foreign language requirements: the specific culture of the studied language. Taken together, if there was one prerequisite for becoming intensely familiar with another culture, it was mastering its specific language. Given the stated ambition of the progressive movement's drive toward multiculturalism, it was somewhat confusing that the need to restore or strengthen foreign language requirements is generally absent from 
the argument and proposals for changes in academic adjustment made in its name (NAS 1996).

None of the other typical humanities subjects—literature, history, philosophy, religion, and fine arts - had ever held the same prestige within the general education requirements that composition and foreign language held. Except for literature in 1914, none of the other humanities subjects were required at a majority of the schools during any of the years examined in the NAS study. From 1914-1964, the NAS study revealed that the percentage of schools with literature requirements dropped from 57 to 38 percent; just 14 percent had a literature requirement in 1993. The credit weight of literature requirements dropped from an average of 4.3 percent in 1964 to 3.3 percent in 1993. Compulsory literature classes or literature classes as part of clusters existed at 75 percent of the institutions studied in 1914; in 1939 and 1964 half of the schools had such courses; by 1993 no schools had them (NAS 1996).

The NAS study highlights how progressive education has become the standard of liberal arts education. These changes represented a sea change of educational vision-one promoted by America's most noted educational philosopher, John Dewey. 


\section{JOHN DEWEY'S PHILOSOPHY}

Although Dewey's 1884 dissertation was never published (and no copy has ever been located), his initial philosophical ideas were born of Immanuel Kant's thoughts on experience. In "Kant and the Philosophic Method," an essay that many scholars speculate contained much of the material from the lost dissertation, Dewey highlighted the idea that mere thinking was not enough when creating ideas. Experience allowed for genuine understanding. Kant, Dewey wrote, was an empiricist, and it was sensory experiencetouching, hearing, and seeing - that revealed the effect of a cause. It was sensory experience that "adds reality or existence to our thoughts" (Dykhuizen 1978; Dewey 1884, 163). Dewey defined experience as the most important addition to his physiological idea of life. When human beings renewed themselves, as they had with the renewal of education, they did it through new experiences and actions. A human being's physical renewal was done by recreating "beliefs, ideals, hopes, happiness, misery, and practices." The stability of any experience, Dewey noted, through renewing social groups, was a fact.

All of the things that made up a social group's experiences_-beliefs, ideals, etc.were born unformed, without a way to communicate, and were devoid of any standard. The indisputable fact, noted Dewey, was that the birth and death of all the elements that make up a social group is reliant on the necessity of education, which, broadly defined, seems to be the immersion of these realities in social experience. Education, for Dewey, 
was the means for the "social continuity of life." Dewey's thoughts on experience further influenced his thoughts on human nature (Dewey 1944, 2).

Human nature, for Dewey, was not fixed. Since human nature changed, Dewey argued that the route to progress was open: there would be a way to overcome or transcend the limits of politics and experience as articulated in the great books. Educators simply had to overcome the old view that human nature was fixed and recognize that human nature could progress. Dewey (1922) wrote that we form habits out of slavery to some outdated social customs. Customs persisted, said Dewey, because people are afraid of new things so we tend to act accordingly.

How, then, should people approach cultural, political, and economic life reasonably if human nature is without boundaries? America's founders held that our unalienable natural rights provided us with the ability and knowledge to both secure our freedom in all things, and also appeal to reasonable instincts. For Dewey, though, the concept of an intelligent, fixed human nature had been discredited long ago by Darwin's theory of evolution (Nichols 1990).

Taken at face value, Dewey's thoughts on human nature were not so different from the ancient's conception. The difference, when digging deeper, was that the ancients understood the problems of passions that were sometimes inherent in new thinking and tried to encourage people to be aware of their potentially harmful consequences and instead appeal to reason. Reasonable people made better decisions, said the ancients, and consequently, made better societies. Dewey disagreed with the ancients on precisely this point. He argued that the existing views of human nature served as a means for social control; they were the ideas by which politicians, parents, teachers, and administrators 
have maintained their power over the people they governed, especially power over children. The method of relying on the existing ideas of human nature, said Dewey, constituted a misuse of a schoolteacher's authority because thereby students had been socially suppressed similarly in the ways that governments suppress the citizenry through political tyranny. The traditional definition of goodness, for instance, is obedience, Dewey thought, and nothing more (Dewey 1922). A new liberating possibility would be more suitable for a world that recognized the necessity of progress. 


\section{DEWEY ON EDUCATION}

Dewey thought that traditional education had three central elements: stated academic aims within fixed methods of instruction, and stable discipline. In order to transfer past ideas on to students it was necessary that they be obedient, open, and submissive. Textbooks and books per se represented the wisdom of the past. Teachers taught textbook material. Traditional education, wrote Dewey, involved subject matter that had been worked out long ago by society's elders, but was obsolete for modern times. Therefore, the chief business of schools was to pass these old ideas on to forthcoming generations. It imposed academics from the outside by teachers who taught students using textbook material (Dewey 1938). Success on the traditional model depended on certain standards, rules of conduct, time-schedules, outlines of classification, and the rules of order that must be maintained. Adhering to this traditional model of education, however, created a barrier to educational progress because it did not allow students to independently discover personal interests. (Dewey 1938).

Dewey's goal was to allow children to learn spontaneously and without having to overcome any difficulties or obstacles—obstacles that created barriers to progress. Dewey's view was that educative growth occurs when impulses are allowed to carry on unimpeded. If a child wanted to play with wooden blocks one day and plastic beads and a length of thread the next, she ought to be able to freely do so.

When such impulses are discouraged, and an interesting pursuit is blocked by obstacles inherent in the situation, the snubbed impulse may contribute to some future 
activity, but it will not seem important or useful. In this way, Dewey's definition of educative circumstances emphasized both the impulses inherent in the student and the obstacles to those impulses characteristic in the work the student must overcome in order to achieve the desired end: progress. Education is as much about the removal of obstacles as it is about pouring content into a student's psyche. The working out of problems and obstacles as the student pursued essential interests caused growth, developed character, and strengthened the will (Edmondson 2006, Dewey 1922).

Dewey argued that instead of rejecting the old impulses outright that traditional education and religion taught that needed exorcising, the student should simply use the instances as points of departure. Dewey never stated in certain terms what these negative impulses were that religion and traditional education taught. Dewey insisted, however, that traditional education with the help of religion, suppressed the "child's curiosity, creativity, and excitement for learning." Dewey suggested that youthful impulses must be freed from adult influence. He also argued that the child's interests ought to be the important factors that determined the activities of the school day instead of pre-planned ideas of study (Edmondson 2006, 22).

Much of this emphasis on natural growth and the removal of obstacles is traceable to the great French thinker Jean-Jacques Rousseau. In fact, Rousseau, who penned his seminal work, Emile, in 1762, motivated and influenced progressive education reformers in Europe and America who sought out informal and unorthodox ways of schooling children. Emile was Rousseau's imaginary student and Rousseau his imaginary teacher. As a teacher, Rousseau allowed Emile to learn through discovery and he manipulated the environment to yield the proper outcomes for healthy growth. Emile's education evolved 
naturally, free from a structured environment, and with minimal overt guidance or sermonizing (Rousseau 1762).

Dewey promoted Rousseau's model of activity-based learning — crafting toys, playing games, and learning life skills appropriate for the labor force, which made schools more practical and realistic. Practicality made schools places of discovery where students would eventually shape certain social outcomes-promote equality, cultural diversity, inclusiveness, civil rights, and create employment opportunities. Traditional academic subjects were subordinate. In other words, unlike the classical model that focused on the soul, the new approach to education sought to make the teaching profession a tool for cultivating new social ideas or for building the current understanding of a healthy society (Ravitch 2000).

Dewey and the Progressives in his time imagined an education model that addressed the emerging industrial order. Reformers pressured the standard bearers of the old model to adjust to a fast changing society. They abandoned the so-called outdated model of education including the idea that the classical curriculum was adequate for modern children. They argued that academics which centered on books stalled society's natural progress, and that it was ill-suited to address the mass of immigrant kids crowding into the schools of swelling cities. These young students needed the training and skills that equipped them for the industrial sector and that also encouraged social bonds; algebra and literature did neither. The Lincoln School at Teachers College in 1917 was one example of an early progressive school (Kliebard 1986). The Lincoln School promoted self-directed activities and abandoned "bookish training." Each year, educators from around the country came to see this new way of doing education where books were 
shelved and cities were erected using plastic blocks and cardboard boxes. Each box or block was cut, pasted, and painted. They formed houses, fire stations, stores, and schoolhouses. Science took the form of personal hygiene and "nature study" (Ravitch 2000, 183-4).

Progressive education did not start with the purpose of establishing different kinds of schooling for students from diverse social classes; one example was Teacher's College, where Dewey taught for twenty-six years. Teachers College was thought of as making the biggest impact on progressive educators from the poorest regions to the most affluent (Ravitch 2000). Teachers College started as a progressive alternative to the classical model. Incorporated in 1880, its aim was to teach young girls "the domestic industrial arts among the laboring classes" (Russell 1937, 5). In other words, the college's goal was domesticating female youth. Consequently, this marketing strategy did not attract young males. Four years later the institution changed its name to the Industrial Education Association adding carpentry and "manual training" courses to its schedule of sewing, cooking, and cleaning (Russell 1937).

In 1887 Teachers College decided to focus on training teachers and changed its name to the New York College for the Training of Teachers. It offered courses in education history, pedagogy, natural science, and art. College donors, though, encouraged the school to focus on the value of "formal discipline" and "developing the intellectual faculties," ideas that the teachers and teachers-in-training would spend much time and resources demeaning in the coming decades. In 1889 Teachers College was the name that stuck, and in 1893 it became the pedagogy department of Columbia University where Dewey influenced modern education for two and a half decades (Ravitch 2000). 
Once the institutions were built, the focus shifted to the curriculum. Dewey's 1898 essay titled "The Primary Education Fetich (sic)" highlighted education's progressive transformation within the curriculum. In Fetich (Fetish), Dewey noted in part that there is a "false education god whose idolaters are legion, and whose cult influences the entire educational system." The 'false god' was the intense study in the beginning years of reading and writing English. "It is almost an unquestioned assumption of educational theory and practice," wrote Dewey, "that the first three years of a child's school life shall be mainly taken up with learning to read and write his own language." Add to the fixation of learning English skills the teaching of a certain amount of 'numerical combinations' (mathematics), and we have the "pivot about which primary education swings." Dewey finished his thoughts in elementary English writing and language skills this way: "The plea for the predominance of learning to read in early school life because of the great importance attaching to literature seems to me a perversion" (Dewey 1898, 244-5).

Taken together, progressive institutions and instructors teaching a new curriculum asked students to imagine how they will live, situations that demanded active, not passive learning. These active learning situations exposed students to a daily routine that involved both vocation and social engagement. One day students may be called on to learn how to wash clothes or prepare meals. The next day might include a tour of the city where children were asked to identify income levels based on house size and style. The Deweyian model of education should consider the way people lived in their daily lives without having to take into account bigger, philosophical ideas. Consequently school was a place where life activities were the focus instead of books. Dewey remarked, "I believe 
that education...is a process of living and not a preparation for future living." (Dewey 1897, 78).

Dewey also considered making moral judgements a job of educators. Dewey wrote that the school was responsible for society's moral guidance and that a school that did not guide students' morals was a derelict of duty. Two things were required for integrating moral guidance into the curriculum: freedom from the outdated classical mode and a strong commitment to child-centered activities that fostered open-ended selfdirected individual growth. Perceived moral truths through new curricula brought new thinking (Dewey 1909).

In a Progressive teaching guide entitled World of Mankind, for example, the teacher is instructed how to instill relative value judgements in $\mathrm{K}-3$ students. At the text's suggestion the teacher was encouraged to take students for walks in town during which they would all stand in front of big and small houses and were asked who they thought lived in the houses: poor or rich. The teacher then asked what the students thought they ate in the different sized houses to point out that the bigger the house, the better the food (Branson 1973).

Even with his unique views of education, Dewey did not like being called the father of progressive education. The school, according to Dewey, was a special place that encouraged teachers to monitor an environment where student's feelings, actions, and thoughts were subtly shaped through the new curriculum. Upon becoming familiar with their new bookless environment, it was important to leave students to discover different things individually_ progressives called this 'discovery learning' — and create new ideas; people only discovered new things through self-revelation. Consequently, students were 
rarely taught directly. Rather, student's thoughts and actions were steered in a controlled environment where experiencing different hands-on activities happened (Dewey 1944, Reese 2001).

Dewey (1944) believed that children did better in school, and made better citizens, not when they were learning the classical subjects and memorizing what he deemed petty facts, but when they were simply happy. He noted that when children had a chance to participate at physical activities, "plays, games, and constructive operations" it relieved them from the "tedium and strain of regular school work" (194). Performing plays and playing games, though, were not just diversions from the classical subjects. Understanding child psychology, Dewey noted, was instrumental in getting students to behave in certain ways, and entertainment mediums like games and stage plays were good tools to shape young minds. For example a stage play might promote an overthrow of an oligarchy; a game could reveal strategic ways to take advantage of another's weakness. Those activities also developed skills for "available occupations" when the academic career ended (Dewey 1944, 196).

It was the responsibility of the educator to engage students in these activities in such a way that prepares them for employment. However, these rich activities should not have been viewed as something laborious or tedious; they should be presented as joyous things that will bring immediate satisfaction when they are real occupations. The educator, though, must confront the problem of subordinating the occupational activities to that of intellectual training or, "forming a socialized disposition." In other words, the "social continuity of life" took precedent; moving social life forward was impossible in the classical model (Dewey 1944, 197). 


\section{CLASSICAL EDUCATION}

Classical education teaches civics, personal independence, humanity, selfreliance, technological improvement, and relative safety and security. Classical education provides students with the means of achieving the goal of becoming well-rounded human beings who will understand the world around them and act according to the great permanent dilemmas in the human situation. Plato described education this way: "If you ask what is the good of education in general, the answer is easy: that education makes good men, and that good men act nobly." Plato continued by revealing to us the ways students prepared to live virtuous lives and pursued excellence of citizenship. Plato described what can be described as educating for genuine freedom, or preparing young people to live in a free society. Although America's Founders similarly thought that a classical form of education was clearly tied to a well-educated and virtuous citizenry, there was not a seamless garment of classical thought from the ancients to the Founders. (Pangle 1980, 21).

Contrary to Dewey, America's Founders believed in a constant human nature. This meant that there were permanent dilemmas that every society had to manage and that the human condition was, in the decisive respect, always marked with imperfections. James Madison, in Federalist 51, reflected on his view of human nature, "But what is government itself but the greatest of all reflections on human nature? If men were angels, no government would be necessary. If angels were to govern men, neither external nor internal controls on government would be necessary" (Federalist 51 1788). 
The implied conclusions Madison drew were similar to those of the classics; men are passionate, and therefore government is necessary as a check on passion. Men are never governed directly by angels or God; rulers are imperfect—both lacking in virtue and in wisdom. Although citizens appeal to passions, leaders are not immune from the influence of passion as evidenced from their desire for power. Thus, internal and external checks on government are necessary. This problem could be better managed with proper institutions and with better education. In order to design a modern alternative to the classic's republic, innovations in government were at hand.

Although Madison and others viewed government as a moderator of society's passion, they rejected any great praise of the distant past. The ways of the past had often exacerbated the problems in human nature. Alexander Hamilton suggested that it would be foolish for his contemporaries to view classical thought as a solution to their political difficulties. In modern times, he wrote, there had been great improvement in political science.

The efficacy of various principles is now well understood, which were either not known at all, or imperfectly known to the ancients. The regular distribution of power, the introduction of legislative balances and checks; the institution of courts composed of judges, the representation of the people in the legislature are wholly new discoveries, or have made their principal progress towards perfection in modern times. They are means, and powerful means, by which the excellences of republican government may be retained and its imperfections lessened or avoided. (Federalist 9)

These new institutions of modernity would contribute to better managing of the problems endemic to human nature. Those problems could not be removed - the tension between the demands of public life and the virtues of private people would remain - but they could be managed in a way that promoted civic health. 
Classical education stressed the importance of excellence through cultural literacy (Rahe 1994). The philosophy of cultural literacy meant to carefully consider and have knowledge of the importance of where you came from and where you were going in the modern world. In this there was much information that spreads over human history and human action. In order to be culturally literate, one assumed that some kind of standard existed that was both timeless and virtuous. While some tweaks and adjustments were sometimes considered, the substance of the standard always remained (Hirsch 1987). This emphasis on cultural literacy derives its purpose from ancient Greek and Roman culture. It was recognized that even in an enlightened country such as America, the stability and persistence of the government depended upon the good opinion of the people. Part of that good opinion comes from a well-functioning government that can protect rights, but it also derives from a population that knows what those rights are and how a government can achieve them. The good opinion of the people, that is, depends on literacy about civics and part of that comes from the classical heritage of America. America's political system came in part from the classical tradition of self-government, as did its language, and its love of the arts, the sciences, philosophy, and religion. Classical education held that there were absolute values because the Greeks and Romans thought that education taught that the philosophy of human excellence involves the willingness to acknowledge an understanding of an existing standard of goodness, and the idea of absolute values was a core concept in education (Hirsch 1987).

Early American education was not simply homegrown. It modeled its ideas of academics and culture after the ancients; American schools, then, modeled their curricula mostly after Great Britain's which taught the classical model: trivium, quadrivium, ethics, 
mathematics, natural sciences, history, and geography. At Cambridge University, which became the epicenter of academic thought of the Puritans, the focus of studies had evolved to some extent from the trivium (grammar, rhetoric, logic) and mathematics, and from the study of philosophy. However, a focus on mathematics had declined by 1700 , and the study of classical thought had a rebirth. The early schools were still governed by the Elizabethan laws of 1561 which required that each student be proficient in rhetoric, logic, and philosophy, and that students be tested in these subjects through public discourse before given a degree. Beyond these requirements, a tutor, who was responsible for up to a half dozen students at a time, would determine the course of study (Krauss 1961).

In order to familiarize students with scholastic thought and the value of human excellence, Cambridge emphasized Latin and Ancient Greek; this was also to instill respect for the language and authority of the ancients. Latin and Greek were not only perfect tools for training the minds of students for careful reading and synthesizing difficult texts. They also introduced students to huge amounts of literature and myth in an effort to instill the importance of timeless questions, virtues and values. Even if students were unable to completely understand all the minutiae of the texts, they were still able to tell the story of what made meaningful lives and productive societies (Kopff 1999).

The study of hard but critical texts written in dead languages eventually became available in English; they were called the Great Books. Young students exposed to the ideas in the Great Books gave learners insight into the great ideas but without having to decipher it in a dead language; it was culture and civilization at a bargain, and there was some usefulness to this flea-market approach to education. 
Classical education understood that even though the ideas, stories, and myths in the Great Books were somewhat difficult for teachers to teach and students to learn, it was important for students to tackle ideas that stretched them - that demanded attention and challenged them intellectually. Hard work and determination brought positive results that nourished the soul. Ancient teachers taught the importance of not only what early texts said, but how they were applied to daily life. Aristotle's Lyceum, for example, was a place for philosophizing about the human condition and studying the natural sciences. The Great Books gave students a look at the timeless and universal elements of the human condition, and they familiarized themselves with the consequences of making poor moral decisions and political judgements. In other words, the Great Books presented valuable ideas on human excellence without delving into Dewey's modernity and humanitarianism (Kopff 1999).

During the founding era students were allowed to pursue their own schedule of post-graduate studies, but were required to spend three years attending public lectures, studying theology, Hebrew, and other Old Testament languages. Participating in regular public arguments and making "three personal responsions in the public schools to a Master of Arts opposing (sic)," was also required. Bachelors of Arts students who did not seek a career in the church or in the university could study at home and receive their degree after paying a discontinuance fee and passing a comprehensive exam (Costello 1948, 42).

Harvard was founded in 1636. In 1640 students were introduced to an amended Cambridge model. In an effort to get students to return, the four-year program was reduced to three. Courses were structured so that all students studied related subjects 
every day. Monday and Tuesday mornings, student studied logic the first year, ethics and politics the second, and arithmetic, geometry, and astronomy the third year. Students spent Monday and Tuesday afternoons debating and defending arguments. Wednesdays students studied Greek, Thursday, Hebrew, and Friday, rhetoric. Saturdays were spent studying divinity and on religious preparation (Krauss 1961). Freshmen, in addition to the core subjects, also studied plant science and history. This schedule allowed for the president to conduct all the classes and have time left over for administrative obligations; it followed the growing trend that students should have a lecture on each subject, followed by individual study, presentation, discussion, and debate. In 1655 the first year was expanded to two years, more attention being given to the study of Greek, Hebrew, logic, and metaphysics (Krauss 1961).

Undergraduates studied Hebrew, Aramaic, Syriac, and theology at Harvard, although not at Cambridge; but the study of theology was limited to instruction from William Ames's Medulla Theologiae or De Conscientia, and Johann Wollebius's The Abridgement of Christian Divinitie. Whole passages were memorized by all students and recited to the president on Saturday morning. Preparing and reading passages from the scriptures during morning and evening prayers provided training in logic, Greek and Hebrew in addition to theology (Kraus 1961).

Political topics began appearing in requirements for the Master's degree at Harvard by 1688, when Thomas Dudley defended the idea that "Temporal Dominion was not founded on Grace." However, it was in the decades just prior to the American Revolution that topics addressing the authority of government, the rights of the people, the relations of states to a commonwealth, and other civic focused subjects, which 
reflected the anger of the times, began appearing on the commencement lists (Kraus 1961, 74).

The first commencement announcement of Kings College mentions "geography, history, husbandry, commerce, and government" among the required curriculum, while the College of Philadelphia plan of 1756 required first year courses that would give the student "a knowledge and a practical sense of his position as a man and a citizen embracing ethics, natural and civil law, and an introduction to civil history, laws and government, and trade and commerce" (Costello 1948, 74).

America is connected to the ancient past in various ways: a language that is packed with Latin and Greek words and concepts; beliefs and confessions of the Christian faith; a hearty belief in scientific practices; and a distinct cultural worldview. These are timeless ideas held by millions of citizens, gleaned through classical education. Those who favor the classical mode of education often wonder why the question is rarely addressed of who these Greeks were, and what did they do that was so great? Exceptional is the scholar that addressed the idea of Greek influence on these American ideas; rarer still are the teachers that attempt to connect the ancient world with modern-day America (Hanson and Heath 1998). The Greeks and Romans taught us a lot, and had a profound impact on America's founders and their education; it takes some doing to not include at least a little classical thought into modern education. Hellenism, for example was required study in early America because of the values it focused on and the early Greek laws that protected them. Solon's teaching of the isonomia (equality of political rights), Cleisthenes's concepts of a democratic polis, Socrates emphasis on logos (right thinking and reasoned argument), and Plato's strong belief in healthy debate or dialogue are prime 
examples. Moreover, Aristotle's idea of the ptocheia (poverty) and that it was fertile ground for civil unrest, and Paul's conviction that pistis (faith) was trust, conviction, and persuasions were Greek ideals and principles that the America's founders clung to (Constantelos 1995).

Christian Hellenism and Constantinople made ample contributions to the cultural ideology of America's young republic. Patriarch Photios's teaching that the basis of lawful government relied on the people's consent and goodwill had taken root in the English schools before they were transplanted to the American colonies. The ancient Greek idea of statesmanship, too, had been resurrected by Photios in the ninth century and heavily influenced the political thought of the Renaissance to the Enlightenment in Western Europe and the early United States. Photios's ideas of government and statesmanship were obvious in young America's desire to institute its own hand-picked government and Jefferson's timely declaration that served its notice (Constantelos 1567).

Hellenic thought became a state of mind and an adopted culture that influenced a society determined to be free and independent; it had the particular blend of political, social, and philosophical principles that influenced and educated the American founders and their generation. The ideas born of Hellenism became the American ethos and helped cement its culture and heritage (Constantelos 1995).

Classical education was structured to encourage learners to philosophize about how they view their culture, and why it is important to understand their history. The classic's goal, too, was to embed an idea within the student of the importance of longstanding customs and traditions, and the laws that protect them. 
In sum, the core values of classical Greek and Roman culture adopted by America and taught in its early schools - government, religion, war, individual rights, the duties of citizenship, and the fundamentals that make classical education-are unique,

unparalleled, and unchanging. They explain both America's cultural dynamics and the longevity through which Western culture has maintained itself. 


\section{A RETURN TO CLASSICAL EDUCATION}

The philosophy of what education is and the duties of citizens that classical education teaches seemed obsolete to Dewey, and many modern educators agree that classical education is both unavailable and impracticable in our modern world because it does not benefit a society heavily reliant on science, technology, and industry. Even in our modern world, classical education is both useful and available; it is useful because it teaches the timeless ideas of who we are and our history in terms of Western culture, customs, religion, government, the concepts of individual rights, the importance of the Judeo-Christian idea, and ideas of human excellence. Classical education is available given that nearly all of the classical ideas are available in book form, and taught by individuals who have dedicated their lives to the classical curricula (Hanson and Heath 2006). Dewey and the Progressives thought differently.

The ultimate Deweyian argument against classical education is that it is for a nontechnological people who have little use for modern things. This makes for education that is outdated and useless to the majority of citizens. Classical education, though, teaches timeless material that values knowledge for its own sake and promotes the public good. It espouses standards of accuracy, logic, beauty, importance, and truth essential to a liberal arts education, and demands moral virtue of its supporters. Classical education prepares human beings to assume their places as responsible citizens in the political order that transcends eras, cultures, and worldviews. In other words, classical education is for all people no matter time and place. 
Modern education has moved further away from its central philosophical and ethical ideas that are so vital if we are going to understand our culture of freedom, leisure, and prosperity. The modern educated and uneducated have a lack of knowledge of Western history, government and civics, and literature; they have even less of grammar, syntax, and aesthetics. The truth in absolute values, moral shame, the Greek tragic view of human life - all the things that define human excellence - is now considered either a shameful embarrassment or some bizarre idea invented by the religious right. However, the timeless lessons in the old texts speak to the universal ideas of human excellence (Hanson and Heath 2006).

In many of his writings, Homer shared what was important in life and the things that made up human excellence. In the sixth book of the Iliad, for example, the Trojan prince Glaucus meets the Greek Diomedes on the battlefield. Diomedes has just defeated several Trojan warriors and is shocked that one more has come out to fight him. "Who are you?" he calls out to Glaucus, who responds at some length and ends by telling Diomedes that he got bored with his father, Hippolachus, and was sent to Troy. Hippolachus tells his son when he left to strive to be the best, always, to always hold himself to the highest standard, and not bring disgrace on the "race of his fathers." Glaucus, at his father's urging, worked to be the best, not for himself alone but for his family and community. In other words, it was not just Glaucus's achievement on the battlefield that defined who he was, but the education on human excellence he had received from his ancestors (Homer 1884).

In striving for this kind of human excellence, Glaucus showed us a level of goodness that was not arrogant. He was not bragging that he thought he should be the 
best, but that this was what his family and community wanted of him. What he thought about himself is not entirely clear. By keeping his family in the forefront of his mind, it allowed him to strive to be the best while remaining humble. Glaucus's level of excellence, furthermore, did not lend itself to subjectivity or relativity; it was absolute and exclusive (Dodington 2012).

Is not what Hippolochus wants for his son what we all want for our children as parents and educators - that in addition to attaining the goals of whatever careers they choose, they also do not let their success distort their views of who they are, where they come from, and what it means to be excellent? Are not those things important for humanity's sake? To say that America's founding generation were classically educated and that it was important in that era is one thing. However, it is something different to assert that this kind of schooling is relevant today. Does it make sense that modern students learn the Iliad and know the same things as Alexander Hamilton?

It could be argued that Dewey's ideas, and their effects on American educational thought, are poorly understood, partly because the transformation from the classical to the progressive mode has evolved incrementally over generations. Because Dewey's ideas were thought to be good at the time, new schools were created hastily without sufficient consideration of his thought. The result has been the decline in academic performance, civic ignorance, cultural illiteracy, and human excellence we see all around us; situations that will not markedly recover until educators acknowledge and understand the philosophical differences between what education was and what it has become. Also, modern educators must grapple with the idea that classical education is an archaic model 
that is unable to provide students with the skills required for modern society. (Edmondson 2006).

It is only when education changes so much that the product of its principles require wholesale alterations in cultural norms - family life, career, government and civics, social bonds etc- that societies crumble; it happened in the ancient world. Dewey (1935) noted that radical change is effected through class struggle and is attributed to active and passive forces: modern science and technology, and the opposing force of older institutions and the habits that formed as a consequence. Dewey invoked Marx as a champion of doing away with the old ways and ushering in anew the idea that people can educate themselves to better economic status and more cultural progress. However, the data in the NAS and ACTA studies are at odds with the idea that the Deweyian model results in better academic performance. 


\section{CONCLUSION}

In 1760 when the first Chief Justice of the United States, John Jay, applied for entry into Kings College (now Columbia University), he was obliged to give a 'rational account of the Greek and Latin grammars, read three orations of Cicero and three books of Virgil's Aeneid in the original Greek, and translate the first ten chapters of John into Latin.' Today one would be hard pressed to find any student, political elite, or intellectual who could replicate the feat (Gummere 1933).

Today we think the future belongs to those who are dealt heavy doses of cultural modernity and technological innovation, and so our academic institutions stress them above all others. Progressive education wants to free students from this so called dead hand of the past. As a result, progressive education has replaced the classical model that schooled so many including America's greatest statesmen. Progressive education has steered students away from civic knowledge and book-focused academics traditionalists thought required for an enlightened polis. Progressives have been vigorously working to reverse the enduring and valuable ideas of classical education for more than two centuries.

To fix the problems within modern education requires a rethinking of what education is. It is time for the state and advocates for education to stop apologizing for, and come to grips with, the unique moral and cultural standards and lessons found in the classical model. If education is something that asks our young people to think about and influence the hot-button social issues of the day, or if it is acquiring specific vocational 
skills, then we might stay the course. If, however, education is something that produces enlightened, cultured, and thoughtful people who hold human excellence in the highest regard, then we need to reconsider our philosophy of education. 


\section{REFERENCES}

Adler, M.J. 1951. Aristotle's Politics. Encyclopedia Britannica. William Benton: Chicago American Council of Trustees and Alumni (ACTA). 2016. A Crisis in Civic Education. ACTA. Retrieved at https://www.goacta.org/images/download/A_Crisis_in_Civic_Education.pdf

Annenberg Public Policy Center. 2014. "Americans know surprisingly little about their government, survey finds" University of Pennsylvania. Retrieved at http://www.annenbergpublicpolicycenter.org/americans-know-surprisingly-littleabout-their-government-survey-finds/

Bloom, A. and James H. Nichols Jr. 1990. "Pragmatism and the U.S. Constitution" from Confronting the Constitution. Washington DC: American Enterprise Institute.

Branson, M.S., Et al. 1973. The Environments We Live In: The World of Mankind. Chicago: Follett.

Center for Survey and Research Analysis. 2000. "Elite College History Survey". University of Connecticut. Retrieved at https://www.goacta.org/images/download/losing_americas_memory.pdf

Constantelos, D.J. 1995. ‘Thomas Jefferson and His Philhellenism.” Journal of Modern Hellenism. Nos 12-13.

Costello, W.T. 1948. The Scholastic Curriculum at Early Seventeenth Century Cambridge. Cambridge: Mass. S.E. Morison. The Founding of Harvard College. Cambridge: Mass

Damon, W. 2011. Failing Liberty 101: How We Are Leaving Young Americans Unprepared for Citizenship in a Free Society. Menlo Park: Hoover Institute. 
Dewey, J. 1884. "Kant and Philosophic Method." The Journal of Speculative Philosophy, Vol. 18, No. 2 pp. 162-174

Dewey, J. 1897. “My Pedagogic Creed.” The School Journal, Volume LIV, Number 3 Pp. $77-80$

Dewey, J. 1898. “The Primary Education Fetish.” The Early Works. Carbondale and Edwardsville: Southern Illinois University Press.

Dewey, J. 1909. Moral Principles in Education. New York: Houghton Mifflin.

Dewey J. 1922. Human Nature and Conduct: An Introduction to Social Psychology. New York: Henry Holt.

Dewey, J. 1935. Liberalism and Social Action. New York. Prometheus.

Dewey, J. 1938. Experience and Education. New York: The Free Press.

Dewey, J. 1944. Democracy and Education. New York: The Free Press.

Dodington, P. 2012. "Knowing Ourselves How the Classics Strengthen Schools and Society" American Educator. Retrieved at http://files.eric.ed.gov/fulltext/EJ973248.pdf

Dykhuizen, G. 1978. The Life and Mind of John Dewey. Illinois: Southern Illinois University Press.

Edmondson III, H. T. 2006. John Dewey and the Decline of American Education. Wilmington: Intercollegiate Studies Institute.

Gummere, R. M. 1933. American Colonial Mind and the Classical Tradition. Cambridge: Harvard University Press.

Hanson, V.D. and John Heath. 1998. Who Killed Homer? New York: The Free Press Herbert, Joanne M., \& R. F.McNergney. 1998. Foundations of Education. Needham Heights, MA: Allyn \& Bacon.

Homer.1884. Iliad. Edited by D.B. Monroe. London: Oxford University Press 
Kirk, R. 1978. Decadence and Renewal in the Higher Learning. South Bend:

Gateway.

Kliebard, Herbert M. 1986. The Struggle for the American Curriculum. Boston: Routledge \& Kegan Paul. Cremin. The Transformation of the School. David L. Angus and Jeffrey E. Mirel, The Failed Promise of the American High School, 1890-1995. New York: Teachers College Press.

Kopff, E. Christian. 1999. The Devil Knows Latin: Why America Needs the Classical Tradition. Wilmington: Intercollegiate Studies Institute.

Krauss, J. W. 1961. "The Development of the Curriculum of Early American Colleges." History of Education Quarterly, Vol. 1, No. 2 Pp. 64-76.

Macedo, S. (2004). Crafting good citizens. Education Next. Spring 2004 / VOL. 4, NO. 2 http://educationnext.org/crafting-good-citizens/

National Association of Scholars. 1996. "The Dissolution of General Education: 19141993." Report Prepared by the National Association of Scholars: Rita C. Zurcher: Research Director.

https://www.nas.org/images/documents/report_the_dissolution_of_general_educat ion_1914_1993.pdf.

National Center for Education Statistics. 2016. "The Condition of Education” (NCES 2016-144), Public School Expenditures. Retrieved from https://nces.ed.gov/fastfacts/display.asp?id=66.

Newseum Institute (NI). 2015. "The 2015 State of the First Amendment.” Washington, DC: Newseum Institute. Retrieved from www.newseuminstitute.org/wpcontent/uploads/2015/07/FAC_SOFA15_report.pdf.

Pangle, T. 1980. Plato: Laws. Chicago: University Press.

Rahe, Paul A. 1994. Republics Ancient and Modern. North Carolina: University Press.

Ravitch, D. 2000. Left Back: A Century of Failed School Reforms. New York: Simon \&Schuster. 
Reese, W.J. 2001. "The Origins of Progressive Education.” History of Education Quarterly, 41: 1-24. doi:10.1111/j.1748-5959.2001.tb00072.x

Rousseau, J.J. 1762. Emile. Translated by Barbara Foxley. London \& Toronto: J.M. Dent and Sons

Russell, E. J. 1937. Founding Teachers College. New York: Teachers College Bureau of Publication.

Schalin, J. 2015. "The Decline of the English Department." Pope Center for Higher Education Policy. Retrieved from http://www.jamesgmartin.center/wpcontent/uploads/2015/09/The-Decline-of-the-English-Department.pdf.

University of Vermont 2017. “A Brief Overview of Progressive Education.” Accessed from http://www.uvm.edu/ dewey/articles/proged.html

U.S. Department of Education (USDE). 2005. "10 Facts About K-12 Funding." USDE Retrieved from https://www2.ed.gov/about/overview/fed/10facts/index.html?exp 